Original Scientific Article

\title{
CHARACTERIZATION OF A NOVEL AVIAN AVULAVIRUS 1 OF CLASS I ISOLATED FROM A MUTE SWAN (CYGNUS OLOR) IN MACEDONIA IN 2012
}

\author{
Aleksandar Dodovski ${ }^{1}$, Zagorka Popova², Vladimir Savić ${ }^{3}$ \\ ${ }^{1}$ Department for Avian Diseases, Faculty of Veterinary Medicine, Ss. Cyril and Methodius \\ University in Skopje, Lazar Pop Trajkov 5-7, 1000 Skopje, Macedonia \\ ${ }^{2}$ Laboratory for Serology and Molecular Diagnostics, Faculty of Veterinary Medicine, \\ Ss. Cyril and Methodius University in Skopje, Lazar Pop Trajkov 5-7, \\ 1000 Skopje, Macedonia \\ ${ }^{3}$ Poultry Centre, Croatian Veterinary Institute, Heinzelova 55, 10000 Zagreb, Croatia
}

Received 17 December 2018; Received in revised form 12 February 2019; Accepted 9 March 2019

\begin{abstract}
Avian avulavirus type 1 (AAvV-1) belongs to the family Paramyxoviridae, genus Avulavirus. Even though belonging to a single serotype, there is great genetic variability between these viruses. On the basis of the available complete fusion (F) gene and whole genome sequences and using the genotype classification system, AAvV-1 viruses are divided in two major groups: class I and class II. Class I viruses are predominantly avirulent viruses and majority of the isolations come from waterfowl and domestic poultry from live bird markets in USA and China although isolations from wild birds are reported globally. In our study we used classical, molecular and phylogenetic tools to characterize an AAvV-1 isolated from a mute swan in Macedonia. Based on the complete $\mathrm{F}$ gene sequence, we have concluded that the virus designated as AAvV-1/mute swan/Macedonia/546/2012 (KP123431) belongs to the class I of AAvV-1 with an avirulent cleavage site motif ${ }^{112} E R Q E R * L^{117}$. The virus could not be assigned to any of the four currently existing subgenotypes $(1 \mathrm{a}, 1 \mathrm{~b}, 1 \mathrm{c}$ or $1 \mathrm{~d})$ of the single genotype 1 of class I viruses. Two distant viruses, isolated from goose in Alaska in 1991 and from goose in Ohio in 1987, shared the highest nucleotide sequence identity of the complete F gene with the isolate in our study: $92.7 \%$ and $92.8 \%$, respectively. This is the first report of isolation of class I AAvV-1 in Southeastern Europe. The asymptomatic nature and the underreporting of sequences from the class I viruses impede the understanding of the molecular epidemiology and evolution of this group of viruses.
\end{abstract}

Key words: AAvV-1, class I, mute swan, Macedonia

\section{INTRODUCTION}

Avian avulavirus type $1(\mathrm{AAvV}-1)$ viruses, also known as Newcastle disease (ND) viruses (NDV), belong to the family Paramyxoviridae, genus Avulavirus (1,2). Although belonging to a single serotype, there is a great genetic variability between these viruses. The present classification system that

Corresponding author: Assoc. Prof. Aleksandar Dodovski, PhD E-mail address: adodovski@fvm.ukim.edu.mk

Present address: Department for Avian Diseases, Faculty of Veterinary Medicine, Ss. Cyril and Methodius University in Skopje, Lazar Pop Trajkov 5-7, 1000 Skopje, Macedonia

Phone: +38923240 752; Mobile: +38975267026

Copyright: (C) 2019 Dodovski A. This is an open-access article published under the terms of the Creative Commons Attribution License which permits unrestricted use, distribution, and reproduction in any medium, provided the original author and source are credited.

Competing Interests: The authors have declared that no competing interests exist.

Available Online First: 20 April 2019

Published on: 15 October 2019

https://doi.org/10.2478/macvetrev-2019-0015 distinguishes two major AAvV-1 groups, class I and class II, is widely used by the international scientific community (3). Due to increasing availability of sequencing techniques and sequences included from previously unreported areas, new genotypes/ subgenotypes are being identified frequently $(4,5)$. Nowadays, based on the complete $\mathrm{F}$ gene sequence, class I consists of one genotype further divided into four subgenotypes (1a, $1 \mathrm{~b}, 1 \mathrm{c}$ and $1 \mathrm{~d}$ ), while class II consists of 18 genotypes, some of them further divided into subgenotypes $(4,5,6)$. The presence of viruses that are unassigned to any of the four genotypes $(4,6$, $7,8)$, combined with the addition of novel viruses may lead towards an extension of the current classification of the class I viruses by designating new subgenotypes. According to the criteria set for the establishment of a new genotype/subgenotype (4), these unassigned viruses possess a sufficient evolutionary distance 
for the designation of new subgenotype but other independent isolations of viruses with separate epidemiological background lack.

Majority of isolations of class I viruses comes from waterfowl and domestic poultry from live bird markets in the USA, China and Hong Kong $(9,10,11,12)$, although isolations from wild birds are reported in Europe, USA, China, Russia, and Japan $(5,6,7)$. The vast majority of these viruses are avirulent $(8,9,11,12,13)$ and because of their low virulence they do not fall under the OIE criteria for declaring a ND outbreak, i.e. no trade restrictions are imposed in the zone or country and the socioeconomic impact is negligible (14). Mutation of low virulent to virulent viruses is a very rare event and this has happened in the past only in two instances for both class I and class II AAvV-1 $(15,16)$. To date, the only class I virus reported to be virulent is the one isolated in the Republic of Ireland during an outbreak of ND in domestic poultry in 1990 (15). It was proven that the cause of the outbreak were few mutations in previously circulating low virulent virus in waterfowl (17). It was suggested that this could be a very rare event, given the negative selection of the $F$ protein and conserved nature of its cleavage site (18). However, in an experimental set up an avirulent virus from a waterfowl origin became virulent in chickens after several passages in air sac and brain tissue, by acquiring a virulent cleavage site pattern (19). This data highlights the need for continuous surveillance for low virulent viruses and use of sensitive diagnostic assays able to detect the diverse genetic makeup of AAvV-1 viruses. Moreover, these studies should be specially designed to detect circulating AAvV-1, as majority of the detections are the result of avian influenza surveillance studies (20).

The detection of virulent NDV in wild birds as a result of an ongoing outbreak in domestic poultry has been reported in Macedonia (21). However, detection of low virulent viruses in wild birds has not been reported in the country so far. The aim of this study was to characterize AAvV-1 isolated from a mute swan in Macedonia using classical, molecular and bioinformatics tools.

\section{MATERIAL AND METHODS}

\section{Sample data and virus isolation}

The virus described in this study was isolated from a mute swan (Cygnus olor) found in the vicinity of the town of Strumica (N 41'26’27. E 22 38'15.) in the southeastern part of Macedonia. The swan demonstrating signs of emaciation and lethargy, was caught on 29 February 2012. On the same day the bird was transferred and quarantined in the zoo in Skopje, where it died a few days later, i.e. on 2 March 2012. Field necropsy was performed and the visceral organs (trachea, lung, liver and kidney) including intestines were sampled and further processed for laboratory investigation at the Faculty of Veterinary Medicine in Skopje. Supernatant of the homogenized organs was inoculated in the allantoic cavity of 11 day old embryonated chicken eggs (ECE) for the isolation of the virus in two consecutive passages according to the international recommended protocol (14).

\section{Haemagglutination inhibition test}

Haemagglutination inhibition (HI) test was performed on the positive haemagglutinating allantoic fluid, harvested separately from the inoculated pool of visceral organs and intestines according to the recommended protocol(14). Standard panel of reference antisera for AAvV serotypes from 1 to 9 (Animal and Plant Health Agency, Weybridge, UK), monoclonal antibody (MAb): 617/161 specific for pigeon variants of AAvV-1 and MAb 7D4 specific for La Sota and F strains (22), were used for characterization of the isolate. To exclude notifiable avian influenza virus, the allantoic fluid was tested using $\mathrm{H} 5$ avian influenza antisera (A/cygnus olor/1/Croatia/2005 H5N1 and A/turkey/Italy/1980 H5N2) and H7 avian influenza antisera (A/turkey/Italy/2732/99 H7N1 and A/turkey/ Italy/8535/2002 H7N3).

Nucleic acid extraction, reverse transcriptase PCR (RT-PCR), real-time RT-PCR

Extraction of viral RNA from the allantoic fluid was done using QIAamp Viral RNA Kit (Qiagen, Hilden, Germany) according to the manufacturer's protocol. One-step real-time RT-PCR's using AgPathID One-Step RT-PCR kit (Thermo Fisher Scientific, Carlsbad, USA) for the detection of the M gene, F gene of mesogenic and velogenic strains and $\mathrm{F}$ gene of the early genotypes were performed (23), while to exclude avian influenza, M gene assay was done as well (24). One-step RT-PCR was performed using OneStep RT-PCR Kit (Qiagen) generating a PCR product of 433 bp (25). To obtain a complete $F$ gene, sequence primers described by Lindh et al., were used (7). The amplified PCR products were visualized in 1.5\% agarose gel stained with ethidium bromide. Clean up of the PCR products was done using PureLink ${ }^{\circledR}$ PCR Purification Kit (Invitrogen, Carlsbad, USA).

\section{Sequencing and phylogenetic analyses}

Purified PCR products were sequenced using Big Dye Terminator v3.1 kit (Applied Biosystems, Foster 
City, USA) with POP-7 polymer (Applied Biosystems) in the ABI Genetic Analyzer 3730 XL (Applied Biosystems). Editing of the sequence data and building a consensus sequence was done using Staden Package version 2.0.0 (26). Alignment using Clustal W method and phylogenetic analyses using Maximum Likelihood method based on the General Time Reversible (GTR) model were done using MEGA $6(27,28)$. The GTR model was selected based on the values for Bayesian Information Criterion and corrected Akaike Information Criterion. First, 183 class I sequences published in previous studies and representing all subgenotypes of genotype 1, the unassigned sequences, and sequences closest to the isolate in this study were downloaded from GenBank. A preliminary analysis including the new isolate was done (data not shown). Based on the results, 85 sequences were selected by omitting sequences from the groups of identical or highly similar sequences and taking into consideration epidemiological data (host/country/year), but providing that the tree topology is maintained. Complete $\mathrm{F}$ gene sequences $(n=85)$ consisting of 1662 positions in the final dataset were used for alignment of the sequences and the phylogenetic interpretation was done using MEGA 6 (28).

\section{RESULTS}

Gross lesions during the field post-mortem examination were empty crop and gizzard, hemorrhages of the proventriculus and inflammation of the pleura and lungs. Isolation of the virus was done on ECE, both from the pools of visceral organs and intestines. Haemagglutinating activity of the allantoic fluid was present after the first passage in both samples. Haemagglutination (HA) titer of the allantoic fluid harvested from the inoculated pool of organs was $1 / 128\left(\log _{2} 7\right)$, while HA titer of the allantoic fluid harvested from the inoculated intestines was $1 / 256\left(\log _{2} 8\right)$. $\mathrm{HI}$ test using panel of reference $\mathrm{AAvV}$ antisera for serotypes 1 to 9 showed positive result using $\mathrm{AAvV}-1$ antiserum only. HI titer using polyclonal NDV antiserum was $1 / 512\left(\log _{2} 9\right)$ in both samples. There was no HI present when using MAb 617/161 and MAb 7D4. Real-time RT-PCR's for detection of the $\mathrm{M}$ gene, $\mathrm{F}$ gene of mesogenic and velogenic strains and $\mathrm{F}$ gene of the early genotypes were all negative. Amplified PCR products gave specific bands for all four primer pairs covering the full length of the F gene of class I AAvV-1 (Fig. 1) and for the primers detecting partial $\mathrm{F}$ gene of class I AAvV-1. Nucleotide sequencing of the cleavage site of the $\mathrm{F}$ gene revealed an amino acid motif specific for avirulent isolates of $\mathrm{AAvV}-1$, with leucine at the position 117 and less than three arginine or lysine residues between the positions 113 to 116, ${ }^{112} E R Q E R^{*} L^{117}$ (14). Phylogenetic analysis by constructing a phylogenetic tree was done using the complete $\mathrm{F}$ gene sequence. The studied virus clustered in the class I AAvV-1, but could not be assigned to any of the current subgenotypes (Fig. 2). GenBank accession number of the complete $F$ gene nucleotide sequence of the isolate AAvV-1/ mute swan/Macedonia/546/2012 is KP123431.

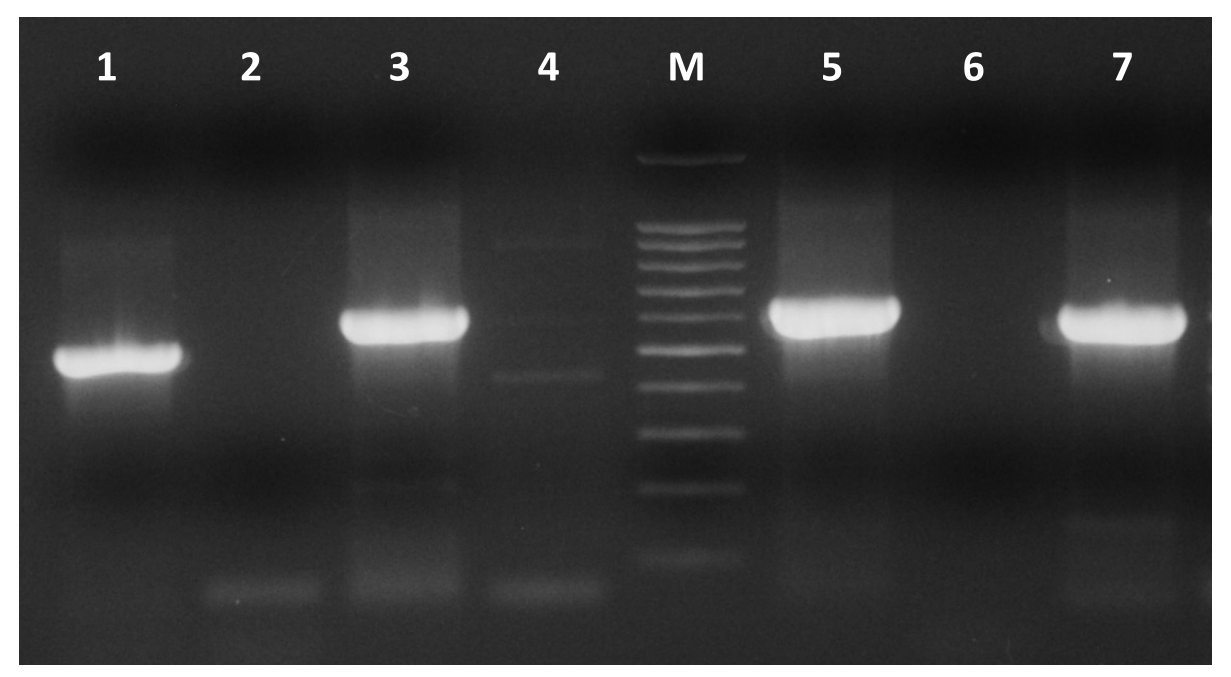

Figure 1. Electrophoresis of PCR products amplified using primers designed by Lindh et al., (7). M - molecular marker 100 - 1000 bp, Lane 1 - primers s1 Hf/s1 h, Lane 2 - negative control, Lane 3 - primers s2 Hf/s2 h, Lane 4 negative control, Lane 5 - primers s3 Hf/s3 h, Lane 6 - negative control, Lane 7 - primers s4 Hf/s4 h 


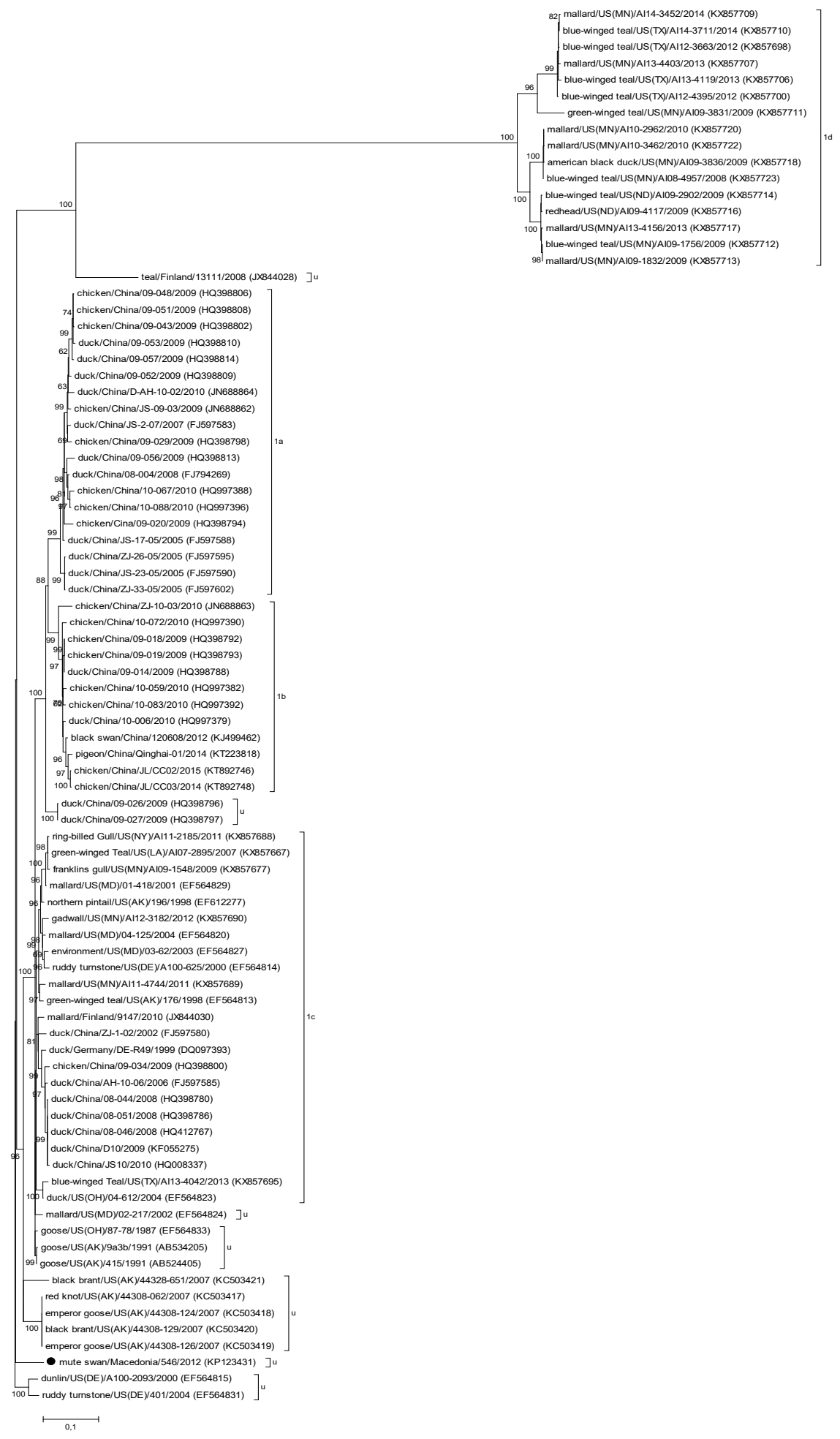

Figure 2. Phylogenetic tree of class I AAvV-1 viruses. The isolate studied here is marked with a black dot. U stands for "unassigned" viruses. The evolutionary history was inferred by using the Maximum Likelihood method based on the General Time Reversible model (27). Initial tree(s) for the heuristic search were obtained by applying the NeighborJoining method to a matrix of pairwise distances estimated using the Maximum Composite Likelihood (MCL) approach. A discrete Gamma distribution was used to model evolutionary rate differences among sites ( 5 categories $(+G$, parameter $=0.5672)$ ). The tree is drawn to scale, with branch lengths measured in the number of substitutions per site. The analysis involved 85 nucleotide sequences. There were a total of 1662 positions in the final dataset. Evolutionary analyses were conducted in MEGA6 (28). GenBank accession numbers are shown in parenthesis 


\section{DISCUSSION}

According to the history, clinical and postmortem data, the mute swan most probably suffered from an underlying disease not related to isolation of the class I AAvV-1. Post-mortem findings indicating an inability to feed, point to the fact that the bird was sick for a prolonged period of time. Being an avirulent virus (cleavage site ${ }^{112} E R Q E R^{*} L^{117}$ ), the presence of the virus itself in the organism of the bird most likely was not the reason for its death. Interestingly, the same scenario of isolation of class I virus from Australian white ibis (Threskiornis molucca) that died from an unknown cause was reported in Australia in 2006 (29). The mute swan was caught near Monospitovo swamp, which is the largest wetland in Macedonia and it is used by various bird species during the nesting period, wintering or as a migration stop. Birds species that are found there include mallard (Anas platyrhynchos), common teal (Anas crecca), wigeon (Anas penelope), garganey (Anas querquedula), black stork (Ciconia nigra), grey heron (Ardea cinerea), little egret (Egretta garzetta) and others (30). The wetland serves as a sampling site and the time period when the bird was caught corresponds to the intensive activity of volunteer hunters engaged in hunting of wild birds for the purposes of active surveillance of avian influenza. Isolation of the virus was incidental and it likely could have happened geographically at another location or country, since the swan would have gotten sick over a different time period or have flown a different route. To date, reported isolations of class I viruses in Europe are from waterfowl and poultry in Denmark, Finland, France and Germany $(3,7,31)$.

Results from the HI tests clearly demonstrated that the isolate is $\mathrm{AAvV}-1$. The negative result using M-gene assay (23) is not unexpected, given its low sensitivity to detect class I viruses as a result of at least six mismatches at the probe site sequence (10).

Phylogenetic analysis of the complete $\mathrm{F}$ gene sequence showed that AAvV-1/mute swan/ Macedonia/546/2012 (KP123431) could not be assigned to any of the four currently existing subgenotypes (1a, 1b, 1c or 1d) of the single genotype 1 of class I viruses (4). Although the virus fulfills the average distance criteria per site (3-10\%) for designation of a new subgenotype (4), it is the only representative in its group, i.e. three more isolates with separate epidemiological background are needed for the establishment of a novel subgenotype, e.g. 1e (Fig. 2). Two distant viruses isolated from goose in Alaska in 1991 (AB524405) and from goose in Ohio in 1987 (EF564833) share the highest nucleotide sequence identity of the complete $\mathrm{F}$ gene with the isolate in our study, $92.7 \%$ and $92.8 \%$, respectively. This fact confirms that there is an absence of sequences to fill the epidemiological gap on the global level. These two similar viruses are also not assigned to any of the four subgenotypes, instead they cluster in two separate groups on the phylogenetic tree. There are nine branches of unclassified viruses that can potentially become novel subgenotypes, if more sequences clustering in these branches become available to meet the criterion of sufficient number of epidemiologically independent isolates (4). Comprehensive phylogenetic data of class I viruses is limited compared to class II viruses (13, 31 ), the latter being isolated from more species and diverse geographical locations. Therefore, in order to understand more thoroughly epidemiology of class I viruses, analysis of a larger number of nucleotide sequences should be performed as they become available (4).

\section{CONCLUSION}

This is the firstreport of isolation of class I AAvV1 in the Southeastern Europe. The asymptomatic nature of class I viruses results in the significant gap of available sequences and detections globally, thus impeding the understanding of the molecular epidemiology and evolution of these group of viruses.

\section{CONFLICT OF INTEREST}

The authors declared that they have no potential conflict of interest with respect to the authorship and/or publication of this article.

\section{ACKNOWLEDGEMENTS}

The complete $\mathrm{F}$ gene sequence in this study has been generated through the Sequencing Services of the Animal Production and Health Sub-programme of the Joint FAO/IAEA Division in Vienna, Austria. 


\section{REFERENCES}

1. Mayo, M.A. (2002). Virus Taxonomy-Houston 2002. Arch Virol. 147, 1071-1076.

PMid:12021875

2. Amarasinghe, G.K., et al. (2018). Taxonomy of the order Mononegavirales: update 2018. Arch Virol. 163, 2283-2294.

https://doi.org/10.1007/s00705-018-3814-x PMid:29637429

3. Czegledi, A., Ujvari, D., Somogyi, E., Wehmann, E., Werner, O., Lomniczi, B. (2006). Third genome size category of avian paramyxovirus serotype 1 (Newcastle disease virus) and evolutionary implications. Virus Res. 120, 36-48.

https://doi.org/10.1016/j.virusres.2005.11.009 PMid:16766077

4. Diel, D.G., da Silva, L.H., Liu, H., Wang, Z., Miller, P.J., Afonso, C.L. (2012). Genetic diversity of avian paramyxovirus type 1: proposal for a unified nomenclature and classification system of Newcastle disease virus genotypes. Infect Genet Evol. 12, 1770-1779.

https://doi.org/10.1016/j.meegid.2012.07.012 PMid:22892200

5. Dimitrov, K.M, Ramey, A.M., Qiu, X., Bahl, J., Afonso, C.L. (2016). Temporal, geographic, and host distribution of avian paramyxovirus 1 (Newcastle disease virus). Infect Genet Evol. 39, 22-34. https://doi.org/10.1016/j.meegid.2016.01.008 PMid:26792710

6. Ramey, A.M., Goraichuk, I.V., Hicks, J.T., Dimitrov, K.M., Poulson, R.L., Stallknecht, D.E., Bahl, J., Afonso, C.L. (2017). Assessment of contemporary genetic diversity and inter-taxa/interregion exchange of avian paramyxovirus serotype 1 in wild birds sampled in North America. Virol J. 14, 43. https://doi.org/10.1186/s12985-017-0714-8 PMid:28253898 PMCid:PMC5335501

7. Lindh, E., Ek-Kommonen, C., Vaananen, V.M., Alasaari, J., Vaheri, A., Vapalahti, O., Huovilainen, A. (2012). Molecular epidemiology of outbreakassociated and wildwaterfowl-derived Newcastle disease virus strains in Finland, including a novel class I genotype. J Clin Microbiol. 50, 3664-3673. https://doi.org/10.1128/JCM.01427-12 PMid:22972821 PMCid:PMC3486212
8. Ramey, A.M., Reeves, A.B., Ogawa, H., Ip, H., Imai, K., Bui, V.N., Yamaguchi, E., Silko, N.Y., Afonso, C.L. (2013). Genetic diversity and mutation of avian paramyxovirus serotype 1 (Newcastle disease virus) in wild birds and evidence for intercontinental spread. Arch Virol. 158, 2495-2503. https://doi.org/10.1007/s00705-013-1761-0 PMid:23807743

9. Kim, L.M., King, D.J., Curry, P.E., Suarez, D.L., Swayne, D.E., Stallknecht, D.E., Slemons, R.D., Pedersen, J.C., Senne, D.A., Winker, K., Afonso, C.L. (2007). Phylogenetic diversity among low virulence newcastle disease viruses from waterfowl and shorebirds and comparison of genotype distributions to those of poultry-origin isolates. J Virol. 81, 1264112653

https://doi.org/10.1128/JVI.00843-07

PMid:17855536 PMCid:PMC2169019

10. Kim, L.M., King, D.J., Suarez, D.L., Wong, C., Afonso, C.L. (2007). Characterization of class I Newcastle disease virus isolates from Hong Kong bird markets and detection using real-time reverse transcription PCR. J Clin Microbiol. 45, 1310-1314. https://doi.org/10.1128/JCM.02594-06 PMid:17287322 PMCid:PMC1865838

11. Liu, X., Wang, X., Wu, S., Hu, S., Peng, Y., Xue, F., Liu, X. (2009). Surveillance for avirulent Newcastle disease viruses in domestic ducks (Anas platyrhynchos and Cairina moschata) at live bird markets in Eastern China and characterization of the viruses isolated. Avian Pathol. 38 (5): 377-391. https://doi.org/10.1080/03079450903183637 PMid:19937525

12. Seal, B.S., Wise, M.G., Pedersen, J.C., Senne, D.A., Alvarez, R., Scott, M.S., King, D.J., Yu, Q., Kapczynski, D.R. (2005). Genomic sequences of low-virulence avian paramyxovirus-1 (Newcastle disease virus) isolates obtained from live-bird markets in North America not related to commonly utilized commercial vaccine strains. Vet Microbiol. $106,7-16$.

https://doi.org/10.1016/j.vetmic.2004.11.013 PMid:15737469

13. Zhu, J., Xu, H., Liu, J., Zhao, Z., Hu, S., Wang, X., Liu, X. (2014). Surveillance of avirulent Newcastle disease viruses at live bird markets in Eastern China during 2008-2012 reveals a new sub-genotype of class I virus. Virol J. 11, 211.

https://doi.org/10.1186/s12985-014-0211-2

PMid:25471313 PMCid:PMC4261539 
14. World Organization for Animal Health (OIE). (2012). Chapter 2.3.14 Newcastle Disease. In: Manual of diagnostic tests and vaccines for terrestrial animals, version adopted May 2012. OIE, Paris. [Accessed December 2018].

http://www.oie.int/fileadmin/Home/eng/Health_standards/tahm/2.03.14_NEWCASTLE_DIS.pdf.

15. Alexander, D.J., Campbell, G., Manvell, R.J., Collins, M.S., Parsons, G., McNulty, M.S. (1992). Characterisation of an antigenically unusual virus responsible for two outbreaks of Newcastle disease in the Republic of Ireland in 1990. Vet Rec. 130 (4):65-68. https://doi.org/10.1136/vr.130.4.65

PMid:1532467

16. Gould, A.R., Kattenbelt, J.A., Selleck, P., Hansson, E., Della-Porta, A., Westbury, H.A. (2001). Virulent Newcastle disease in Australia: molecular epidemiological analysis of viruses isolated prior to and during the outbreaks of 1998-2000. Virus Res. 77, 51-60.

https://doi.org/10.1016/S0168-1702(01)00265-9

17. Collins, M.S., Franklin, S., Strong, I., Meulemans, G., Alexander, D.J. (1998). Antigenic and phylogenetic studies on a variant Newcastle disease virus using anti-fusion protein monoclonal antibodies and partial sequencing of the fusion protein gene. Avian Pathol. 27, 90-96.

https://doi.org/10.1080/03079459808419279

PMid:18483969

18. Miller, P.J., Kim, M.L., Ip, H.S., Afonso, C.L. (2009). Evolutionary dynamics of Newcastle disease virus. Virology 391, 64-72.

https://doi.org/10.1016/j.virol.2009.05.033

PMid:19564032

19. Shengqing, Y., Kishida, N., Ito, H., Kida, H., Otsuki, K., Kawaoka, Y., Ito, T. (2002). Generation of velogenic Newcastle disease viruses from a nonpathogenic waterfowl isolate by passaging in chickens. Virology 301, 206-211.

https://doi.org/10.1006/viro.2002.1539

PMid:12359423

20. Rehman, Z.U., Meng, C., Sun, Y., Mahrose, K.M., Umar, S., Ding, C., Munir, M. (2018). Pathobiology of Avian avulavirus 1: special focus on waterfowl. Vet Res. 49, 94-104. https://doi.org/10.1186/s13567-018-0587-X PMid:30231933 PMCid:PMC6148804
21. Dodovski, A., Krstevski, K., Dzadzovski, I., Naletoski, I. (2015). Molecular detection and characterization of velogenic Newcastle disease virus in common starlings in Macedonia. Vet Arch. $85,635-645$.

22. Alexander, D.J., Manvell, R.J., Kemp, P.A., Parsons, G., Collins, M.S., Brockman, S., Russell, P.H., Lister, S.A. (1987). Use of monoclonal antibodies in the characterisation of avian paramyxovirus type 1 (Newcastle disease virus) isolates submitted to an international reference laboratory. Avian Pathol. 16, 553-565.

https://doi.org/10.1080/03079458708436406 PMid:18766645

23. Wise, M.G., Suarez, D.L., Seal, D.L., Pedersen, J.C., Senne, D.A., King, D.J., Kapczynski, D.R., Spackman, E. (2004). Development of a realtime reverse-transcription PCR for detection of Newcastle disease virus RNA in clinical samples. J Clin Microbiol. 42, 329-338.

https://doi.org/10.1128/JCM.42.1.329-338.2004 PMid:14715773 PMCid:PMC321685

24. Spackman, E., Senne, D.A., Myers, T.J., Bulaga, L.L., Garber, L.P., Perdue, M.L., Lohman, K., Daum, L.T., Suarez, D.L. (2002). Development of a real time reverse transcriptase PCR assay for type A influenza virus and the avian $\mathrm{H} 5$ and $\mathrm{H} 7$ haemagglutination subtypes. J Clin Microbiol. 40, 3256-3260.

https://doi.org/10.1128/JCM.40.9.3256-3260.2002

PMid:12202562 PMCid:PMC130722

25. Liu, H., Zhao, Y., Zheng, D., Lv, Y., Zhang, W., Xu, T., Li, J., Wang, Z. (2011). Multiplex RT-PCR for rapid detection and differentiation of class I and class II Newcastle disease viruses. J Virol Methods. 171, 149-155.

https://doi.org/10.1016/j.jviromet.2010.10.017

PMid:21034772

26. Staden, R., Judge, D.P., Bonfield, J.K. (2001). Sequence assembly and finishing methods. In: Baxevanis, A.D., Francis Ouellette, B.F. (Eds.), Bioinformatics A Practical Guide to the Analysis of Genes and Proteins Second Edition (pp. 302-322). John Wiley \& Sons.

https://doi.org/10.1002/0471223921.ch13

27. Tamura, K. (1992). Estimation of the number of nucleotide substitutions when there are strong transition-transversion and $\mathrm{G}+\mathrm{C}$-content biases. Mol Biol Evo. 9, 678-687.

PMid:1630306 
28. Tamura K., Stecher G., Peterson D., Filipski A., Kumar, S. (2013). MEGA6: Molecular Evolutionary Genetics Analysis version 6.0. Mol Biol Evo. 30, 2725-2729.

https://doi.org/10.1093/molbev/mst197

PMid:24132122 PMCid:PMC3840312

29. Gordon, A., Field, H. (2006). A cross-jurisdictional model for targeted surveillance of wild bird species. Final report on Wildlife Exotic Disease Preparedness Program project, Department of agriculture, fisheries and forestry, Australia. [Accessed December 2018]. http://www.agriculture.gov.au/SiteCollectionDocuments/animal-plant/emergency/wildlifeexoticdiseaseprogram/08-09/cross-jur-wild-bird-surveillance.pdf.
30. Velevski, M. (2008). Birds. In: Melovski, L., Ivanov, G., Angelova, N., Velevski, M., Hristovski, S. (Eds.), Monospitovo blato: the last marsh in Macedonia (pp. 37-42). Municipality Bosilovo.

31. Aldous, E.W., Mynn, J.K., Banks, J., Alexander, D.J. (2003). A molecular epidemiological study of avian paramyxovirus type 1 (Newcastle disease virus) isolates by phylogenetic analysis of a partial nucleotide sequence of the fusion protein gene. Avian Pathol. 32, 239-257.

https://doi.org/10.1080/030794503100009783

PMid:12850913 